\title{
INTERACTION LINKS OF HEALTHCARE INSTITUTIONS WITHIN ONE HOSPITAL DISTRICT
}

DOI: $10.36740 /$ WLek202103236

\author{
Mykola P. Stovban, Vasyl M. Mykhalchuk, Alexander K. Tolstanov, Vira V. Maglona \\ SHUPYK NATIONAL MEDICAL ACADEMY OF POSTGRADUATE EDUCATION, KYIV, UKRAINE
}

\begin{abstract}
The aim: Theoretical substantiation and determination of the main characteristics of the interaction links of medical institutions within one hospital district in the conditions of aggravation of the epidemiological situation in Ukraine on the analysis basis of the legislative base and elaboration of literary sources.

Materials and methods: In the work is used a range of methods: content analysis, bibliosemantic, systematic approach, analysis of products of activity.

Conclusions: The authors propose a doctrinal definition of the term "hospital district". The key problems of the domestic healthcare sector in the context of a pandemic have also been identified. The author points out that in order to successfully reform the health care system and the effective interaction of hospitals in one hospital district, it is necessary to pay attention to funding sources and proper legal regulation, as without the latter any initiatives will have no legal force and will be ignored. health care may be ineffective.
\end{abstract}

KEY WORDS: hospital district, health care, health care facilities, medical reform, interaction mechanism

Wiad Lek. 2021;74(3 p.II):756-760

\section{INTRODUCTION}

Analyzing the events in Ukraine on the reform of all spheres of society and the state in connection with bringing strategically important state systems in line with international and European standards, we can state that in this aspect of the greatest resonance, the health care system has had a devastating impact.

The pandemic caused by COVID- 19 in 2020 posed a very serious challenge to the international health care system as a whole, but the greatest stress and burden came from national health care structures and the Ukrainian one, unfortunately, was no exception and demonstrated obsolescence, incompetence and lack of equipment. appropriate tools and the complete impossibility of fighting the pandemic and providing medical services to the citizens of Ukraine.

However, all the above rather negative events have once again proved that the development of medicine is one of the main indicators of sustainable development of the country, because other areas of life can't exist if the health care system is low. So, as we have seen, without effective control of epidemics and without good protection against disease, people will not be particularly interested in secondary needs if the need to maintain health comes first.

Given the above, today we can talk about a long, complete leveling of the real problems of the health care system. Today in Ukraine there is a rather extensive and inefficient health care system. Participants in the medical field (hospitals, laboratory centers of the Ministry of Health, health centers, medical statistics centers, monitoring and evaluation departments) act inconsistently, duplicate their functions, need additional resources (financial, property) and change their management system.

\section{THE AIM}

The aim of the article is theoretically substantiate and determine the main characteristics of the interaction of medical institutions within one hospital district in the context of exacerbation of the epidemiological situation in Ukraine based on the analysis of the legal framework and the study of literature sources.

\section{MATERIALS AND METHODS}

In the work is used a range of methods: content analysis, bibliosemantic, systematic approach, analysis of products of activity.

\section{REVIEW}

The issue of research of links and interaction of health care institutions in the context of universal values of the welfare state is extremely relevant today and arouses increased scientific interest among medical scientists and researchers of public administration and legal processes. Leiberyuk O.M Babinets L.S, Bogaichuk V.G, Borovik I.O, Tkach O.O, Matyuk L.M, Bulakh I.V,Zakhidna O.O are devoted to the problems of formation of hospital districts. R., Midlyk Yu. I., Kachur O. Yu., Mamchin M.M, Pariy V.D, Roshchin G.G, Mazurenko O.V, Dorosh V.M, Pagava O.Z, Ivanov V.I Babinets L.S, Bogaychuk V.G, Borovik I.O, Tkach O.O, Matyuk LM identified the main challenges to the health care system in terms of decentralization, the priority of primary care and the formation of hospital districts, considering the experience of Ternopil region.

However, as we can see, most of the mentioned researchers pay special attention to the issues of creation and 
functioning of hospital districts in the health care system. However, in our opinion, it is the links of interaction of health care institutions within one hospital district that need a thorough scientific research, because the development and functioning of this interdependence has a direct impact on the regulation of the most important area of public administration - human life and health.

The Constitution of Ukraine enshrines that Ukraine is a sovereign and independent, democratic, social, legal state. Man, his life and health, honor and dignity, inviolability and security are recognized in Ukraine as the highest social value [1].

According to Article 12 of the International Covenant on Economic, Social and Cultural Rights, everyone has the right to medical care and medical care in the event of illness. The key article of Ukrainian legislation, which regulates the fundamental principles of human rights in the field of health care and establishes the foundations of the national health care system is Article 49 of the Constitution of Ukraine [2].

Chapter 22 "Public Health" of the Association Agreement between Ukraine and the European Union defines Ukraine's European aspirations to strengthen the health care system and its potential, increase its safety and protect human health as a prerequisite for sustainable development and economic growth, development developed and sustainable democracy and market economy, in particular Article 427 defines the main areas of cooperation between Ukraine and the European Union, primarily through "strengthening Ukraine's health care system and its capacity through reforms" [3].

In order to properly comply with the above norms, the Ministry of Health in 2016 proposed and supported the World Health Organization "Concept for the reform of health care financing in Ukraine." In accordance with the provisions of this concept, the reform of the medical sector in Ukraine is proposed to be carried out in the following areas:

1) optimization of medical infrastructure by closing or re-profiling institutions with low workload and weak technical base and creation of large intensive care hospitals;

2) redistribution of resources through the introduction of a new mechanism for financing medical services:

- introduction of a co-payment system, when the state makes a clear commitment to provide a predetermined free amount of medical services, and citizens have to pay for additional services privately;

- gradual transition to payment to medical institutions of the final result of actually provided medical services on the principle of "money follows the patient";

- granting medical budgetary institutions financial and managerial autonomy by transforming them into state and municipal non-profit enterprises;

3) the transition from command-administrative methods to the state-public management model [4].

As can be seen from the Concept of Health Care Financing Reform, the integration and optimization of the health care sector requires the creation of hospital districts, for decision-making on secondary health care facilities among cities of regional significance, districts and united territorial communities [5, p.11].

Before researching the interaction between health care facilities, it is necessary to dwell on the definition of the term "hospital district". Among the doctrinal definitions, the definition proposed by Mykhalchuk V.M. occupies a prominent place, noting that the hospital district is a territorial association of health care institutions of several districts into a single medical space on the criterion of accessibility, population, existing medical institutions [6, p.161]

Regarding the normative definition of the term "hospital district", it should be noted that this was regulated by the Resolution of the Cabinet of Ministers of Ukraine of November 27, 2019 № 1074 "Some issues of hospital districts", according to which the hospital district was defined as a functional association of security institutions health, located in the relevant territory, which provides secondary (specialized) and emergency medical care to the population of such territory [7].

However, on June 19, 2020, the Cabinet of Ministers of Ukraine № 589 amends the previously adopted resolution of November 27, 2019 № 1074 "Some issues of creating hospital districts". The changes, in particular, concern the conceptual apparatus of the Procedure for the creation of hospital districts. Therefore, the term "hospital district" is removed, but at the same time the Procedure is supplemented by a new term "health care facilities", which is proposed to mean multidisciplinary health care facilities of state and communal ownership, which meet the criteria for defining a multidisciplinary hospital. treatment of the first or second level or can be increased to it [8].

Also, within the hospital district will be provided:

- systematic interaction between the subjects of the hospital district;

- efficient use of resources of the health care system and investments for the development of a capable network of the hospital district;

- modernization of the medical care system, etc. [8].

Another innovation of the above-mentioned Resolution of the Cabinet of Ministers of Ukraine is that the competence of the Ministry of Health includes the right to form a commission to consider proposals to determine the list of health care support institutions, which may include representatives of the Ministry of Health and other central executive bodies. state bodies, the public and public associations, international organizations [8].

Therefore, given the above circumstances, we consider it necessary to propose our own doctrinal definition, according to which the hospital district is proposed to understand the voluntary association of communities (in a single medical space) as a system of technologically related but legally and financially autonomous hospitals located throughout area or part (depending on the size of the area, population density, infrastructure), which is formed in order to increase the availability of medical services and care for patients. 
The hospital district must include at least one multidisciplinary intensive care unit of the first and / or second level and other health care facilities. The center of the hospital district is defined as a settlement (which is geographically closest to the center of the district), usually a city with a population of over 40 thousand people, which houses a multidisciplinary intensive care hospital of the second level. Today, the Cabinet of Ministers of Ukraine approved the list and composition of hospital districts in 13 regions of Ukraine (Dnipropetrovsk, Zhytomyr, Zaporizhia, Kyiv, Poltava, Luhansk, Ternopil, Rivne, Khmelnytsky, Kherson, Chernihiv, Chernivtsi regions and Kyiv) [9].

Moreover, a capable network should be established within the hospital district, consisting of health care support facilities and other health care facilities, including multidisciplinary children's hospitals, perinatal centers, specialized centers and health care facilities that provide medical care for oncological, infectious diseases, tuberculosis and other socially significant diseases. That is, almost every hospital district includes: medical-diagnostic center, planned and rehabilitative treatment hospitals, ambulance station with ambulance stations, temporary-based ambulance stations and specialized ambulance crews, hospice (palliative care facility) care and psychological support for the terminally ill). Primary health care centers for primary health care are based on the administrative territory of hospital districts [6].

Provision of diagnostic tests for the needs of primary care and planned outpatient specialized care will be provided by outpatient departments of hospitals of planned treatment or consultative-diagnostic polyclinics. In acute cases, outpatient specialized care will be provided by hospital specialists for intensive care [6].

As we can see, the hospital district is a kind of tool for community cooperation to decide on secondary health care facilities among cities of regional significance, districts and OTG. That is, the hospital district is a collaboration tool for network planning. The following indicators have been set in Ukraine as planned: 200 thousand populations per level II intensive care hospital, 120 thousand per level I hospital [10].

Thus, the hospital council is a platform for negotiation and assistance in the interaction of health care facilities within the hospital district. The latter does not make any decisions, but only allows to work out solutions, to develop a common vision - what should be the future of the hospital network of this district as a whole. As V.M. Mykhalchuk notes, with whom we fully agree: "The task of the hospital council is to develop a draft 5-year development plan for the hospital district. And therefore - to determine what investments are needed to bring hospitals to the modern level " $[6, \mathrm{p} .171]$.

However, with the establishment of hospital councils and the empowerment to create multi-year district development plans based on the interaction of health care facilities, it is assumed that the latter will be realistic and therefore supported by all communities, the state and the international community as a whole. attracting additional funds for the development of the health care system in Ukraine.

A new effective mechanism of the regional hospital interaction with the health care facilities of the hospital district is the creation and operation of a training center for continuous postgraduate training of medical workers (doctors, paramedics) on the basis of the regional hospital. This will effectively improve the professional skills of all medical workers of the regional hospital and other medical institutions of the district [11, p.306].

We unequivocally believe that in order to successfully reform the health care system and the effective interaction of hospitals in one hospital district, it is necessary to pay considerable attention to funding sources. Additional sources of funding should be: charitable assistance and grant funds; voluntary health insurance funds; payment of the hospital for the provision of services under agreements; receipts for services provided by the hospital in addition to the standards of free medical care; for services provided to patients on their own initiative; voluntary contributions and donations, and other sources not prohibited by current legislation [12].

Therefore, in order to ensure the interaction and effective functioning of hospital districts, it is advisable to base the formation of a model for managing their development cross-sectoral management approach as a way to identify and implement new opportunities to solve pressing problems based on coordination of interests and integration of public, governmental, business institutions [5].

All subjects of intersectoral interaction and cooperation should be focused on the development of hospital districts, active participation in the implementation of the basic functions of the implementation of management mechanisms, namely [13]:

- regulatory - the development of levers and ways to stimulate the establishment of relations between the subjects of interaction in the process of solving problems of health care development;

- preventive - the implementation of opportunities for cooperation to prevent threats in the development and implementation of strategic goals for the development of hospital districts;

- integrative - pooling of resources on the basis of partnership in the implementation of development projects;

- diagnostic - identification and representation of interests and opportunities of subjects of intersectoral cooperation and identification of problems that need to be addressed as a matter of priority;

- innovative - search and introduction of innovative technologies in the context of achieving the goal of creating hospital districts.

\section{DISCUSSION}

Thus, our study shows that the interaction of health care institutions within one hospital district is a driving force in strengthening the state health care system, is its main component, as it solves the most important issues on the ground, namely the preservation of life and human health [14]. 
Although the hospital district does not act as a separate legal entity, a separate level of territorial organization of power, but it plays the role of a mechanism for coordination and joint decision-making by representatives of local authorities, whose territories it covers. The boundaries and composition of each district are formed on the basis of the criteria for the formation of the district, established by the Procedure for the establishment of hospital districts.

As a result of the study, we can say that hospital districts are created as "functional associations of hospitals located in a certain area." The health care facilities covered by the hospital district remain the property and subordination of the local authorities that are members of the hospital district.

We can note that the next step in improving secondary health care is the creation of hospital councils to coordinate actions, develop proposals for the organization, operation of health care within a single hospital district, preparation and approval of long-term development plans for hospital districts for 5 years. resources). To finance the gradual restructuring of hospital health care facilities, it is proposed to create a separate program of the State Budget. Optimizing the network through hospital districts will solve most of the problems of the secondary level of health care, as it will balance the local autonomy and controllability of the process by the Government, as well as create appropriate financial incentives [15].

\section{CONCLUSIONS}

Thus, the innovation process in the field of health care is the key to the effective functioning of health care facilities, the achievement of general medical goals and the provision of timely care to sick people. The study showed that the innovation process requires the use of a procedurally oriented approach in the management of health care organizations, which will strengthen the interaction of health care facilities within one hospital district, and the latter in turn will not only overcome urgent problems, but also will open new perspectives for the development of the national health care system.

\section{REFERENCES}

1. Konstituciya Ukrayini. Dokument 254k/96-VR [The Constitution of Ukraine. Document 254k / 96-BP]. (in Ukrainian).

2. Mizhnarodnij pakt pro ekonomichni, socialni i kulturni prava. Dokument 995-042 [International Covenant on Economic, Social and Cultural Rights. Document 995-042]. (in Ukrainian).

3. Ugoda pro asociaciyu mizh Ukrayinoyu z odniyeyi storoni, ta Yevropejskim Soyuzom, Yevropejskim spivtovaristvom z atomnoyi energiyi i yihnimi derzhavami-chlenami, $z$ inshoyi storoni. Dokument № 984-011[Association Agreement between Ukraine, of the one part, and the European Union, the European Atomic Energy Community and their Member States, of the other part. Document № 984-011]. (in Ukrainian).

4. Koncepciya reformi finansuvannya sistemi ohoroni zdorov'ya Ukrayini, pidgotovlena robochoyu grupoyu z pitan reformi finansuvannya ohoroni zdorov'ya pri MOZ Ukrayini: proekt [The concept of health care financing reform in Ukraine, prepared by the working group on health care financing reform at the Ministry of Health of Ukraine: draft]. (in Ukrainian).
5. Stovban M.P., Stovban I.V. Osnovni harakteristiki sistemi vzayemodiyi medichnih zakladiv v mezhah odnogo gospitalnogo okrugu. [The main characteristics of the system of interaction of medical institutions within one hospital district]. Scientific research. 2020;3 (30): 11-18. (in Ukrainian).

6. Mykhalchuk V.M., Stovban M.P. Osoblivosti vzayemodiyi medichnih zakladiv odnogo gospitalnogo okrugu v umovah zagostrennya epidemiologichnoyi situaciyi. [Features of interaction of medical institutions of one hospital district in the conditions of aggravation of an epidemiological situation]. Scientific perspectives. 2020; 2 (20): 158-176. (in Ukrainian).

7. Postanova Kabinetu Ministriv Ukrayini vid 27 listopada 2019 r. № 1074 "Deyaki pitannya stvorennya gospitalnih okrugiv [Resolution of the Cabinet of Ministers of Ukraine of November 27, 2019 № 1074 “Some issues of creating hospital districts"]. (in Ukrainian).

8. Postanova Kabinetu Ministriv Ukrayini vid 19.06.2020 roku № 589 «Pro vnesennya zmin do Postanovi Kabinetu Ministriv Ukrayini vid 27.11.2019 roku № 1074». Dokument № 589-2020-p. [Resolution of the Cabinet of Ministers of Ukraine of June 19,2020 № $589^{\prime \prime}$ On Amendments to the Resolution of the Cabinet of Ministers of Ukraine of November 27, 2019 № 1074". Document № 589-2020-n]. (in Ukrainian).

9. Yuridichni aspekti funkcionuvannya likaren v mezhah gospitalnih okrugiv. Proekt USAID «Pidtrimka reformi ohoroni zdorov'y [Legal aspects of the functioning of hospitals within hospital districts. USAID Health Care Reform Support Project]. (in Ukrainian).

10. Metodichni rekomendaciyi z pitan peretvorennya zakladiv ohoroni zdorov'ya z byudzhetnih ustanov na komunalni nekomercijni pidpriyemstva [Methodical recommendations on transformation of health care institutions from budgetary institutions into communal non-profit enterprises]. (in Ukrainian).

11. Heese H. S. Specialization and competition in healthcare delivery networks. Health Care Management Science. 2019; 12(3):306-324.

12. Slabky G.O., Lobas V.M. Organizaciya diyalnosti oblasnoyi likarni v umovah reformuvannya sistemi medichnoyi dopomogi naselennyu. Metodichni rekomendaciyi [Organization of the regional hospital in terms of reforming the system of medical care]. 2013. (in Ukrainian).

13. Koshova S. P. Krut A.H. Harakteristika stresostijkosti ta adaptivnogo potencialu pri navchanni likariv v pislyadiplomnij osviti [Characteristics of stress resistance and adaptive potential in the training of doctors in the system of postgraduate education].URL: https://www.researchgate. net/publication/329041763_Characteristics_of_stress_resistance_ and_adaptive_potential_in_the_training_of_doctors_in_the system_of_postgraduate_education. (in Ukrainian).

14. Andrushchenko H., Shandova N., HburZ. etal. Enterprise competitiveness management by introducing virtual reality technologies. Academy of Strategic Management Journal 2019; 18(1): 1-6.

15. Kotliar L., Akimov 0., Krasivskyy 0. et al. Assessment of Possibility of Integration of Experience of Leading Countries of The World in Training of Public Administration Specialists. Sys Rev Pharm 2020; 11(11): 656662. doi:10.31838/srp.2020.11.95.

This study was conducted within scientific and research (initiative-search) work of Shupyk National Medical Academy of Postgraduate Education entitled "Substantiation of innovative management models and optimization of organizational forms of activity of bodies, enterprises and health care institutions" (2020-2024, № state registration 01200U101680). 
ORCID and contributionship:

Mykola P. Stovban: 0000-0002-6576-7494 ${ }^{D, E, B}$

Vasyl M. Mykhalchuk: 0000-0002-5398-4758 ${ }^{\mathrm{A}}$

Alexander K. Tolstanov: 0000-0002-7459-8629 C, F

Vira V. Maglona: 0000-0002-8653-7102 ${ }^{B}$

\section{Conflict of interest:}

The Authors declare no conflict of interest.

\section{CORRESPONDING AUTHOR}

Mykola P. Stovban

Shupyk National Medical Academy of Postgraduate Education

9 Dorohozhytska Str., 04112 Kyiv, Ukraine

tel: +380678540967

e-mail: ernest-natan@ukr.net

Received: 11.10 .2020

Accepted: 05.03 .2021

A - Work concept and design, B - Data collection and analysis, C - Responsibility for statistical analysis,

D-Writing the article, $\mathbf{E}$-Critical review, $\mathbf{F}$ - Final approval of the article 